\title{
PENGARUH JENIS FESES TERNAK BERBEDA SEBAGAI MEDIA KULTUR TERHADAP PERTAMBAHAN POPULASI CACING TANAH (Lumbricus rubellus)
}

\section{The Effect of Different Types of Animal Stool as a Culture Media on Population Addition Soil Worms (Lumbricus rubellus)}

\author{
Muhammad Hasby \\ Staf Pengajar Program Studi Budidaya Perairan \\ Fakultas PertanianUniversitas Islam Riau \\ Email: hasbi_muhammad@agr.uir.ac.id \\ [Diterima: Desember 2017; Disetujui: Maret 2018)
}

\begin{abstract}
This research aims to determine the test of the effect of different types of feces of livestock as a culture media on the increase in earthworm populations (L. rubellus). The research was conducted for 42 days starting on October 19 - November 30, 2017, at the Fish Seed Center (BBI) Faculty of Agriculture, Riau Islamic University, Pekanbaru. The method used in this study was an experimental method using a Completely Randomized Design (CRD) with five treatments and three replications. The treatments used as experiments in this study were: P0: using $100 \%$ soil, P1: using $100 \%$ buffalo feces, P2: using $100 \%$ goat manure, P3: using $100 \%$ cow dung, P4: using $25 \%$ soil + buffalo feces 25 $\%+$ goat feces $25 \%+$ cow feces $25 \%$. Treatment experiments were carried out on earthworms (L. rubellus). The container used is 15 units of the tray (tray) with a size of $30 \mathrm{x} 40 \mathrm{~cm}$ that has been filled with fecal treatment media and soil as high as $10 \mathrm{~cm}$ with 160 individual stocking densities. As a result, it was known that the highest increase in earthworm population is found in the treatment of P1 using 100\% buffalo feces with a population increase of 7926 individuals and the lowest was in the P0 treatment using $100 \%$ of the soil where there was no increase in earthworm population (L rubellus). Analysis of variance showed that Fcount 68,01> Ftable $(0,01) 9,77$ were at the accuracy level of $99 \%$, where the administration of different types of feces to the increase in earthworm populations (L. rubellus) had significantly different. Climatic data in the form of average temperature measurement ranged from 24-280C, Humidity 4-10 (moisture meter) and $\mathrm{pH}$ of media during the study ranged from 6,4-7.
\end{abstract}

Keywords: Earthworms, Feces, Soil, Population

\section{ABSTRACT}

Penelitian ini bertujuan untuk mengetahui uji pemberian pengaruh jenis feses ternak yang berbeda sebagai media kultur terhadap pertambahan populasi cacing tanah (L. rubellus). Penelitian ini dilaksanakan selama 42 hari di mulai pada tanggal 19 Oktober - 30 November 2017, bertempat di Balai Benih Ikan (BBI) Fakultas Pertanian Universitas Islam Riau Pekanbaru. Metode yang digunakan pada penelitian ini adalah metode eksperimen menggunakan Rancangan Acak Lengkap (RAL) dengan lima perlakuan dan tiga ulangan. Perlakuan yang dijadikan eksperimen pada penelitian ini yaitu: P0: menggunakan 100\% tanah, P1: menggunakan 100\% feses kerbau, P2: menggunakan $100 \%$ kotoran kambing, P3: menggunakan 100\% kotoran sapi, P4: menggunakan tanah $25 \%$ + feses kerbau $25 \%$ + feses kambing $25 \%$ + feses sapi $25 \%$. Percobaan perlakuan dilakukan terhadap cacing tanah (L. rubellus). Wadah yang digunakan adalah 15 unit nampan (tray) dengan ukuran $30 \times 40 \mathrm{~cm}$ yang telah diisi media perlakuan feses dan tanah setinggi $10 \mathrm{~cm}$ dengan padat tebar 160 individu. Berdasarkan hasil penelitian yang dilakukan, diketahui bahwa pertambahan populasi cacing tanah yang tertinggi terdapat pada perlakuan P1 yang menggunakan $100 \%$ feses kerbau dengan pertambahan populasi sebanyak 7926 individu dan terendah terdapat pada perlakuan P0 yang menggunkan $100 \%$ tanah dimana tidak adanya pertambahan populasi cacing tanah (L. rubellus). Analisis variansi menunjukkan bahwa $F_{\text {hitung }} 68,01>F_{\text {tabel }}(0,01) 9,77$ pada tingkat 
ketelitian 99\%, dimana pemberian jenis feses ternak yang berbeda terhadap pertambahan populasi cacing tanah (L. rubellus) sangat berbeda nyata. Data klimatik berupa rataan pengukuran suhu berkisar antara $24-28^{\circ} \mathrm{C}$, Kelembaban 4-10 (moisture meter) dan $\mathrm{pH}$ media selama penelitian berkisar antara 6,4-7.

Kata kunci: Cacing tanah, Feses, Tanah, Populasi

\section{PENDAHULUAN}

Cacing tanah (Lumbricus rubellus) merupakan hewan yang tidak asing lagi dilingkungan masyarakat, hewan kecil yang hidup di tanah ini memiliki banyak manfaat yang terkandung di dalam tubuhnya yang terdiri dari gizi yang cukup tinggi. Terutama protein sebesar $64-76 \%$. Kandungan lain yang terdapat pada tubuh cacing antara lain adalah lemak 7$10 \%$, calsium $0.55 \%$, fosfor $1 \%$ dan serat kasar $1.08 \%$. protein yang terdapat pada tubuh cacing tanah terdiri 9 macam asam amino esensial dan 4 macam asam amino non-esensial (Wanasuria, 1997). Budidaya cacing tanah dapat dilakukan dengan memanfaatkan feses hewan ternak.

Pengelolaan limbah yang dihasilkan oleh hewan ternak peliharaan masyarakat kurang memperhatikan lingkungan sekitar yang sering mencemari lingkungan, baik dari bau tidak enak dan menyengat sampai mecemari perairan sungai. Limbah peternakan seperti Feses sapi merupakan limbah organik yang mengandung gizi yang cukup tinggi. Menurut Gaddie dan Douglas (1978) protein (17,31\%), Fosfor (1,78 $\%$ ) dan Kalsium (2,88 \%). Feses kerbau protein $8 \%$, lemak $1 \%$, serat residu $8,3 \%$, serat kasar $7,8 \%$ dan abu 2,6\% (lab. UNRI, 2017). Feses kambing mengandung air $(8,28 \%)$, protein kasar $(14,41 \%)$, lemak $(3,59 \%)$, serat kasar $(24,38 \%)$, Abu (16,37\%), kalsium $(0,68 \%)$ dan fosfor (1,08\%) (Suhermiyati, 1984). Pemanfaatan feses ternak sebagai media budidaya cacing tanah sangatlah membantu masyarakat dalam menanggulangi permasalahan limbah ini. Sehingga masyarakat sangat terbantu dengan adanya pemanfaatan feses hewan yang dapat digunakan dalam kegiatan budidaya cacingL.rubellus yang selama ini menjadi faktor pencemar lingkungan sehingga menjadikannya bahan yang dapat dimanfaatkan dalam kegiatan perikanan.

Berdasarkan uraian diatas penulis tertarik untuk melakukan penelitian tentang pengaruh jenis feses ternak berbeda sebagai media kultur terhadap pertambahan populasi cacing tanah (Lumbricus rubellus).

\section{METODE PENELITIAN}

Penelitian dilakukan di Balai Benih Ikan (BBI) Fakultas Pertanian Universitas Islam Riau, Pekanbaru. Selama 42 hari dimulai pada 19 Oktober - 30 November 2017.

Bahan yang digunakanpada penelitian ini adalah induk cacingtanah (L.rubellus),feses kerbau,feses kambing, feses sapi dan tanah. Sedangkan Alatyang digunakan adalah nampan plastik, rak kayu, alat semprot (hand sprayer, sarung tangan, $\mathrm{pH}$ meter, moisture meter dan thermometer.

Penelitian ini menggunakan Rancangan Acak Lengkap (RAL) block dengan 3 perlakuan dan 4 ulangan. Adapun perlakuan yangdigunakan:

$\mathrm{P} 0=$ Penggunaan tanah $100 \%$

$\mathrm{P} 1=$ Penggunaan feses kerbau $100 \%$

P2 = Penggunaan kotoran kambing $100 \%$

P3 = Penggunaan kotoran sapi $100 \%$

$\mathrm{P} 4=$ Penggunaan tanah $25 \%+$ feses kerbau $25 \%+$ feses kambing $25 \%+$ feses sapi $25 \%$.

\section{Parameter Yang Diamati}

Pengukuran pertambahan populasi dilakukan setelah pemeliharaan selama 42 hari atau selama 6 minggu pemeliharaan, menggunakan metode sampling dengan mengambil 4 titik pengambilan sampel di dalam wadah penelitian. Setelah menghitung jumlah cacing disetiap sampel maka dirataratakan, setelah rata-rata cacing didapat langkah selanjutnya menghitung jumlah total media maka dengan jumlah media yang diperoleh, dikalikan dengan rata-rata sampel lalu akan didapatkan jumlah pertambahan populasi setelah dikurangi jumlah awal populasi cacing tanah (L. rubellus). Data klimatik yang diukur meliputi suhu media, pHdan kelembaban setiap satu minggu sekali. 


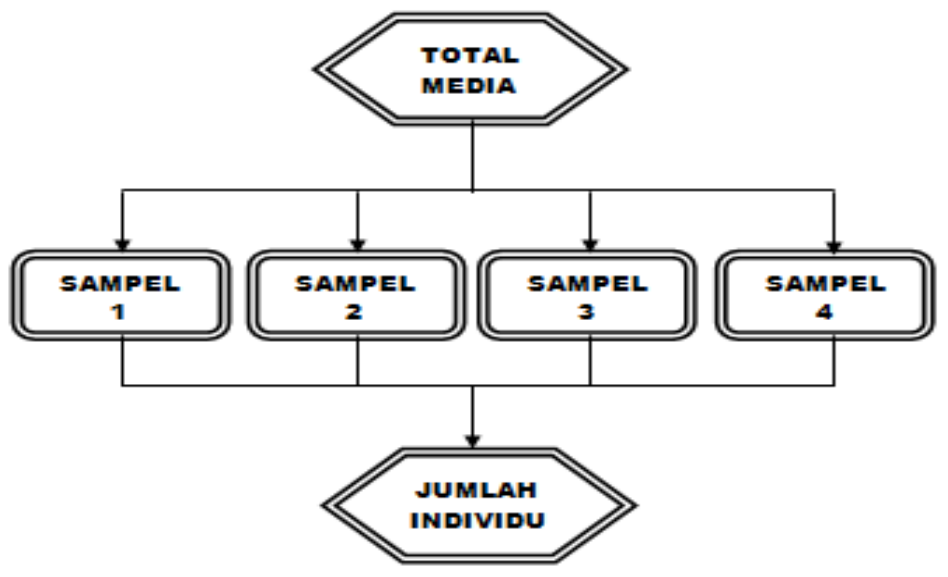

Gambar 1. Metode Sampling

\section{Analisis Data}

Data hasil pengukuran pertambahan populasi dianalisis dengan uji $\mathrm{F}$ (sidik ragam) pola Rancangan Acak Lengkap (RAL). Bila anava menunjukkan $\mathrm{F}$ hitung $<\mathrm{F}$ tabel taraf 95\%, maka tidak ada pengaruh perlakuan dan bila $\mathrm{F}$ hitung > F tabel $99 \%$ maka perlakuan ini berpengaruh sangat nyata (Sudjana, 1992). Hasil analisa variansi data yang menunjukkan perbedaan sangat nyata akan dilanjutkan dengan uji Newman-Keuls.

\section{HASIL DAN PEMBAHASAN}

\section{Pertambahan Populasi}

Berdasarkan pengamatan selama penelitian, rata-ratapertambahan populasi cacing tanah (L. rubellus)tertinggi terdapat pada perlakuan P1sebesar 7.926 ind dan terendah pada perlakuan P2 sebesar 4.479 ind. Data kelulushidupan dapat dilihat pada Grafik 1.

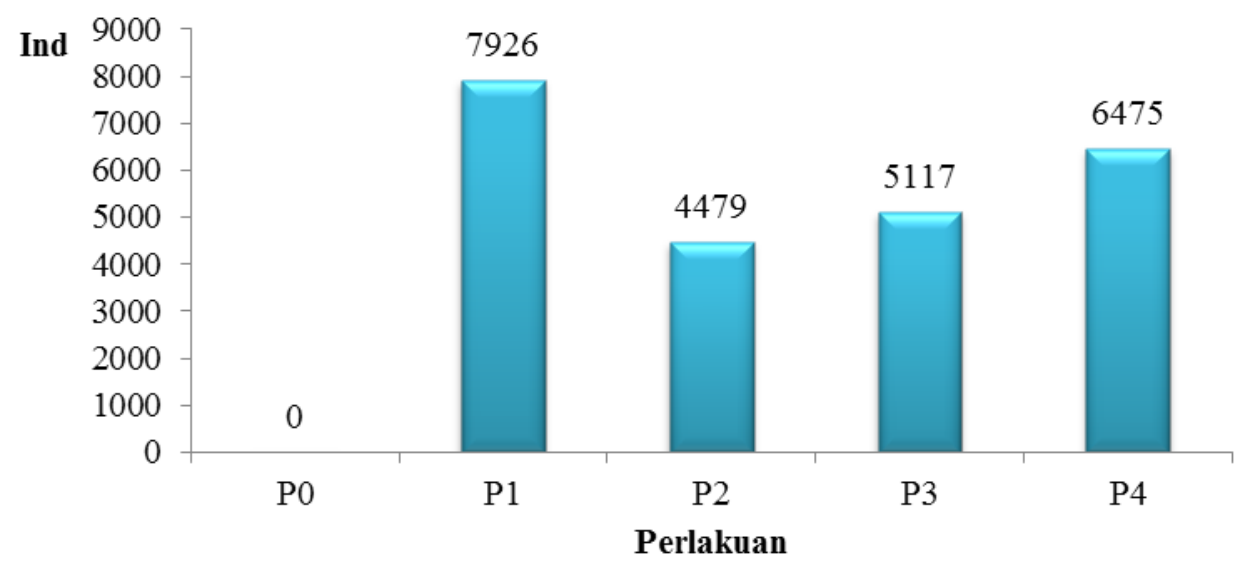

Grafik 1. Rerata Pertambahan Populasi Cacing Tanah (L. rubellus) sehingga memudahkan cacing dalam

Banyaknya jumlah pertambahan populasi pada perlakuan P1 yang menggunakan feses kerbau $100 \%$ dipengaruhi oleh serat yang terdapat pada feses kerbau lebih halus dibandingkan dengan hewan ternak lain memanfaatkan feses kerbau sebagai makanan selain itu media uji feses kerbau lebih gembur dibandingkan media uji lainnya.

Minnich dalam Sutanto (2012) yang menyatakan faktor kegemburan sarang merupakan persyaratan penting untuk kecepatan produksi dan untuk mencegah terkumpulnya 
gas yang bersifat asam dalam media. kandungan serat yang halus dan media yang gembur menjadikan P1 lebih banyak pertambahan populasi.

Pengamatan yang dilakukan selama penelitian feses sapi sebagai media uji tidak dimanfaatkan langsung oleh cacing sebagai makanan ini dapat diamati dari feses cacing (kascing) yang dihasilkan dipermukaan media uji pada minggu pertama. Aktifitas cacing baru meningkat pada minggu ketiga dimana kascing sudah mulai terlihat dipermukaan media serta meningkatnya $\mathrm{pH}$, lambatnya aktifitas cacing yang menjadikan pertambahan populasi tidak lebih baik dari perlakuan P1 dan P4, dimana kokon belum sempat menetas pada pemeliharaan 42 hari. Cacing tanah lebih menyukai feses sapi yang mengalami proses pembusukan dari pada feses sapi yang masih baru.
Sihombing (1999) menyatakan bahwa pakan berupa feses sapi harus didiamkan selama tiga minggu sebelum dijadikan makanan bagi cacing tanah. Dari pernyataan tersebut dan hasil penelitian yang dilaksanakan media uji feses sapi harus didiamkan selama tiga minggu baru dapat diberikan kepada cacing tanah $(L$. rubellus). Selanjutnya Sutanto (2001) menjelaskan cacing tanah lebih menyukai bahan organik yang sedang mengalami dekmposisi dari pada yang masih segar ataupun yang sudah terkomposisi.

\section{Jumlah Kokon, Juvenil dan Immature}

Jumlah tertinggi kokon, juvenil dan immature terdapat pada perlakuan P1 sebanyak berturut-turut 98 ind, 306 ind dan 7620 ind. Sedangkan perlakuan terendah terdapat pada perlakuan P0 yang tidak ditemukannya kokon, juvenil dan immature pada media penelitian. Lebih jelasnya dapat dilihat pada Grafik 2.

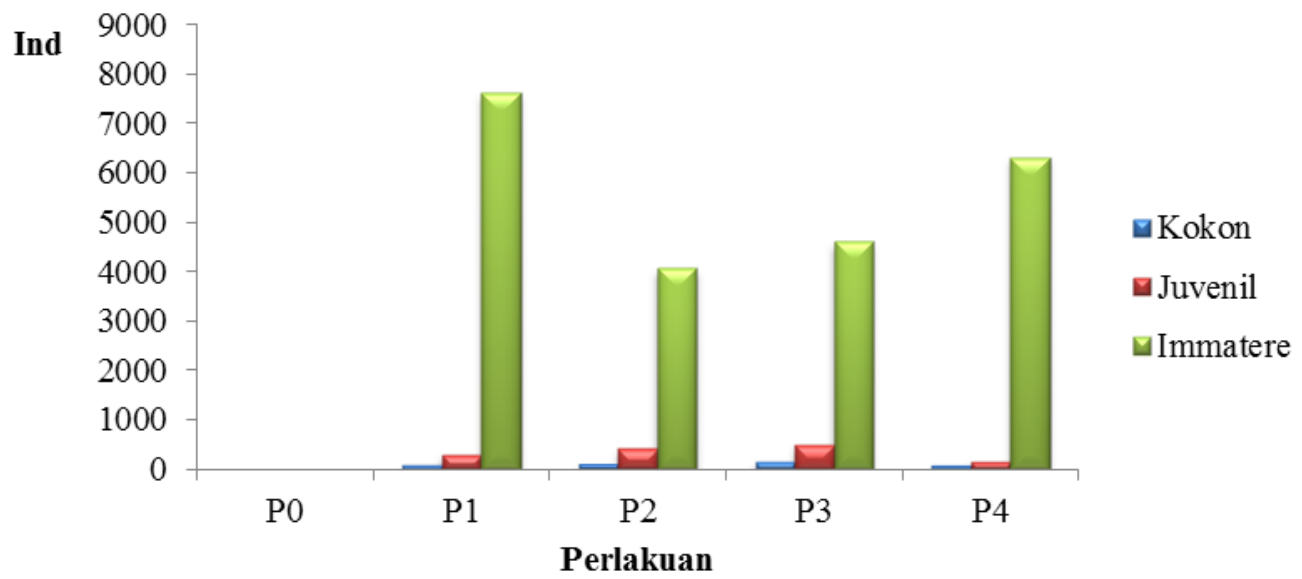

Grafik 2.Rerata Jumlah Kokon, Juvenil dan Immature Cacing Tanah (L.rubellus)

Banyaknya jumlah kokon dan juvenil pada media perlakuan P3 diakhir penelitian ini dipengaruhi oleh aktifitas cacing baru belangsung pada minggu ketiga dimana feses sapi pada pengamatan minggu pertama hingga kedua belum ada aktifitas cacing tanah ditandai tidak adanya kascing dipermukaan media, selain dari jumlah kascing yang terlihat peningkatan $\mathrm{pH}$ media juga membuktikan aktifitas cacing dengan naiknya $\mathrm{pH}$ pada pengamatan ketiga. Wahyono (2011) mengatakan cacing tanah dapat mengeluarkan kapur dalam bentuk kalsium karbonat $\left(\mathrm{C}_{\mathrm{a}} \mathrm{CO}_{3}\right)$ atau dolomit pada lapisan tanah sehingga $\mathrm{pH}$ tanah meningkat. Media feses sapi pada minggu pertama belum dapat melakukan reproduksi

karena keadaan media uji belum cocok untuk bereproduksi sehingga cacing tanah baru mulai bertelur pada minggu ketiga, dari beberapa kelemahan penggunaan feses sapi yang menjadikan perlakuan P3 rendah pertambahan jumlah populasi sehingga tidak lebih banyak.

Tingginya jumlah immature pada perlakuan P1 yang menggunakan $100 \%$ feses kerbau,dari pengamatan yang dilakukan cacing tanah pada minggu pertama dapat langsung beradaptasi dengan media uji dan aktifitas 
cacing dapat terlihat langsung dari banyaknya kascing pada permukaan media. Media yang gembur dan berporos menjadiakan feses kerbau memenuhi syarat yang dibutuhkan cacing dalam bereproduksi dan berkembang oleh karena itu jumlah immature diakhir penelitian cukuplah banyak dibandingkan perlakuan P0, P2, P3 dan P4 pada pemeliharaaan 42 hari. Minnich dalam Sutanto (2001) yang menyatakan faktor kegemburan sarang merupakan persyaratan penting untuk kecepatan produksi.

\section{Data Klimatik}

Hasil pengukuran faktor klimatik berupa suhu media, kelembaban media dan $\mathrm{pH}$ media dapat dilihat pada Grafik 3.

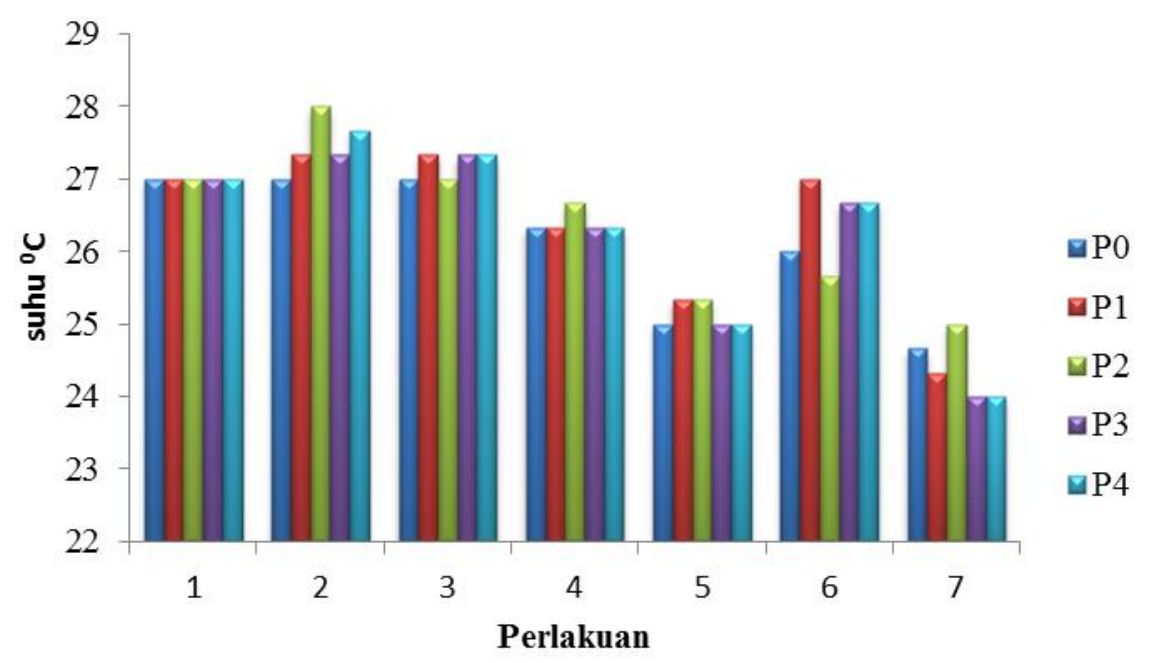

Gratık 3. Kerata Suhu Medıa

Suhu rata-rata media pemeliharaan dalam penelitian ini, yang diamati pada pengukuran pertama hingga ke 7 berkisar antara $24-28{ }^{\circ} \mathrm{C}$ dengan rata-rata suhu pada semua perlakuan 26 ${ }^{\circ} \mathrm{C}$. Pada pengamatan pertama hingga keempat suhu relatif tinggi sedangkan pada pengukuran kelima hingga ketujuh suhu media menjadi rendah, suhu selain dipengaruhi oleh media juga dipengaruhi oleh suhu lingkungan dan cuaca selama penelitian.
Pengamatan ini sesuai dengan penelitian yang dilakukan oleh Khaidir (2018) Setiap pengukuran pada media penelitian menghasilkan suhu yang berfluktuatif pada setiap pengamatan selain dipengaruhi oleh media, suhu lingkungan atau cuaca juga mempengaruhi hasil pada setiap pengamatan.

Data pengukuran kelembaban media selama penelitian dapat dilihat pada Grafik 5.

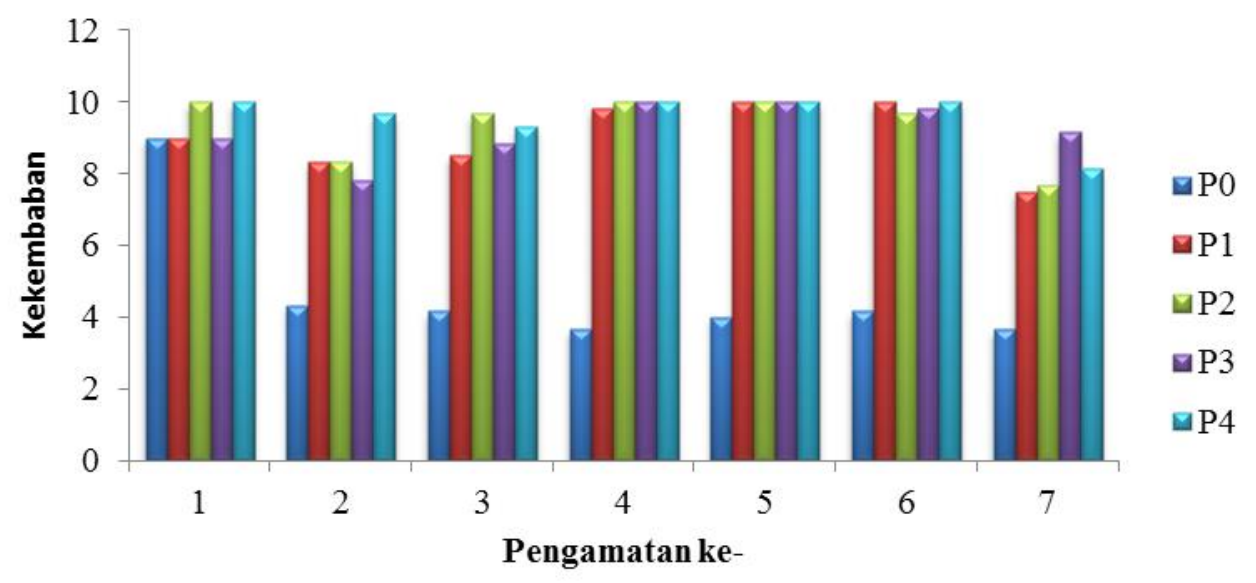


Gambar 5. Rerata Kelembaban Media

Dalam mempertahankan kelembaban media penelitian, tingkat penyiraman yang cukup tinggi terjadi pada P0 yang menggunakan tanah $100 \%$, penguapan yang tinggi ditambah dengan tanah yang tidak dapat mempertahankan air secara maksimal menjadikan perlakuan P0 sangat mudah kering dan memadat sehingga perlu dilakukan penyiraman setiap harinya. Ketersediaan bahan organik feses hewan pada media uji sebagai sumber makanan menjadikan cacing tanah $(L$. rubellus) terus melakukan pergerakan dalam mencari makanan. Pergerakan cacing tersebut membentuk lubang - lubang sehingga media lebih gembur dan tingkat kelembaban lebih dapat bertahan, dibandingkan perlakuan yang tidak tersedianya bahan organik seperti perlakuan P0 100\% tanah, dimana cacing kurang melakukan pergerakan yang aktif karena tidak tersedianya makan pada media uji. Sehingga cacing tanah (L. rubellus berdiam diri di dasar media. Media dalam melakukan budidaya cacing tanah (L. rubellus) harus dalam keadaan lembab yang sesuai dengan kebutuhan hidup cacing dimana Sihombing (2002) mengatakan bahwa kelembaban yang dibutuhkan cacing tanah berkisar antara 60\%$90 \%$. Selanjutnya media yang terlalu basah yang menggenangi liang cacing tanah akan sulit bernafas, kurangnya aerasi dalam tanah yang terlalu basah cacing akan keluar mencari tempat yang lebih kering (Anonim, 2011).

Data pengukuran $\mathrm{pH}$ media selama penelitian dapat dilihat pada Gambar 6.

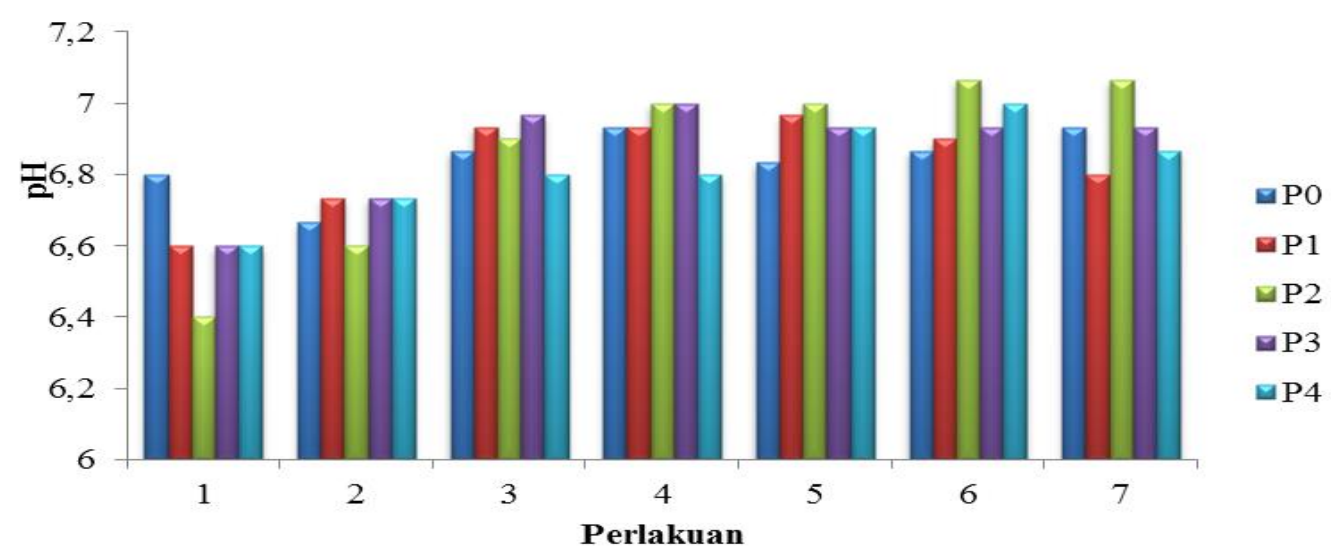

Gambar 6. Rerata pH Media

Penelitian pengukuran pertama hingga pengukuran kedua memiliki tingkat keasaman lebih rendah dibandingkan dengan pengamatan ketiga hingga ketujuh berkisar antara 6,4-6,7. Pada pengukuran ke tiga hingga ketujuh mengalami peningkatan $\mathrm{pH}$ mejadi netral berkisar antara 6,8-7. $\mathrm{pH}$ selama penelitian sangat memenuhi syarat dalam kehidupan cacing. Nugraha (2009) menjelaskan agar pertumbuhan cacing tanah menjadi baik, keasaman media harus netral, media yang sedikit asam cacing tanah masih dapat hidup, keasaman media ideal untuk cacing tanah berkisar 6-7,2. Maka pH pada media uji cukup ideal selama penelitian.

Adanya peningkatan $\mathrm{pH}$ media selama penelitian dipengaruhi adanya aktifitas makan cacing tanah (L. rubellus), hanya yang terus meningkat pada media uji setiap harinya. Cacing tanah akan terus memakan bahan organik feses kerbau yang tersedia selama penelitian, namun setelah proses pencernaan pada cacing tanah (L. rubellus) selesai, sisa bahan organik yang tidak habis dicerna akan keluar melalui anus yang disebut kascing (bekas cacing). Kascing bersifat netral dengan semakin banyaknya kascing pada media perlakuan menjadikan media uji mengalami peningkatan $\mathrm{pH}$.

Wahyono (2011) mengatakan cacing tanah dapat mengeluarkan kapur dalam bentuk kalsium karbonat $\left(\mathrm{C}_{\mathrm{a}} \mathrm{CO}_{3}\right)$ atau dolomit pada lapisan dibawah tanah sehingga $\mathrm{pH}$ tanah meningkat. Cacing tanah memanfaatkan bahan organik sebagai makanan, bahan organik ini selanjutnya menjadi pupuk organik setelah 
dimakan oleh cacing tanah, yang dikenal kascing, kascing bersifat netral dengan nilai $\mathrm{pH}$ rata-rata 6,8 (PPMBR, 2013).

Maka kenaikan $\mathrm{pH}$ media pada pengamatan ke empat menjadi netral dipengaruhi aktifitas makan cacing terus mengalimi peningkatan pada pengukuran keempat serta kemampuan cacing tanah dalam mengeluarkan kapur dalam bentuk kalsium karbonat $\left(\mathrm{C}_{\mathrm{a}} \mathrm{CO}_{3}\right)$ atau dolomit pada proses pencernaan makanan.

\section{KESIMPULAN DAN SARAN}

\section{KESIMPULAN}

Berdasarkan hasil dan pembahasan dapat disimpulkan :

1. Penggunaandanpemanfaatan jenis feses ternak yang berbeda memberikan pengaruh terhadap pertambahan populasi cacing tanah (L. rubellus).

Analisis variansi menunjukkan bahwa $F_{\text {hitung }} 68,01>F_{\text {tabel }(0,01)} 9,77$ pada tingkat ketelitian $99 \%$, dimana jenis feses ternak berbeda terhadap pertambahan populasi cacing tanah (L. rubellus) sangat berbeda nyata.

2. Feses kerbau $100 \%$ merupakan komposisi terbaik, dengan pertambahan populasi sebanyak 7926 individu cacing tanah (L. rubellus) dari 160 individu awal selama 42 hari pemeliharaan.

3. Hasil pengukuran faktor klimatik berupa rataan pengukuran suhu berkisar $24-28{ }^{\circ} \mathrm{C}$, sedangkan kelembaban berkisar antara 4-10 namun media harus dilakukan penyiraman setiap harinya guna mempertahankan kelembaban dan $\mathrm{pH}$ media selama penelitian berkisar antara 6,4-7 maka pH cukup ideal selama pemeliharaan.

\section{Saran}

Dalam budidayakan cacing tanah ( $L$. rubellus) dapat menggunakan nampan plastik berukuran $10 \times 30 \times 40(\mathrm{~cm})$, dangan sistem bertingkat dan menggunakan bahan organik yang berasal dari feses kerbau sebagai makanan dan media hidup.

\section{DAFTAR PUSTAKA}

Anonim. 2011. Tingkah Laku Cacing Tanah. http://zonabawah.blogspot.co.id. Diakses pada 23 Januari 2018.

Gaddie, R.E dan D. Douglas. 1997. Earthworms for Ecology Profit. Vol. 2. Scientific Earthworm Farming. California. 252 hal.

Khaidir, M. 2018. Pemberian Feses Kerbau dengan Komposisi yang Berbeda sebagai Media Kultur terhadap Pertambahan Populasi Cacing Tanah (L. rubellus). Skripsi. Jurusan Perikanan Prodi Budidaya Perairan. Fakultas Pertanian Universitas Islam Riau. Riau.

Nugraha, E. 2009. Potensi Manfaat Budidaya Cacing Tanah. Titian Ilmu. Bandung. 76 hal.

PPMBR. 2013. Pupuk Kascing (Bekas Cacing). Universitas Gadjah Mada.

Sihombing, 2002. Pemanfaatan Limbah Ruminansia untuk Mengurangi Pencemaran Lingkungan. Makalah. Program Pasca Sarjana Institut Pertanian Bogor. Bogor .

Sudjana. 1992. Desain dan Analisis Eksperiment. Tarsito Bandung. 285 hal.

Suhermiyati, S. 1984. "Pengujian Cobaan Bahan Limbah RPH dan Ragi Makanan Ternak serta Kombinasinya dalam Ransum Ayam Pedaging”. Thesis. Fakultas Peternakan IPB, Bogor.

Sutanto, D.C. 2001. Pertumbuhan Bobot Badan dan Mortalitas Cacing Tanah (Lumbricus rubellus) yang Mendapat Pakan Sisi Makanan Warung. Skripsi Program Studi Teknologi Produksi Ternak. Fakultas Peternakan. IPB. Bogor.

Wahyono. 2011. Klasifikasi, Jenis, dan Sifat Cacing Tanah. Kanasius. Yogyakarta 210 hal.

Wanasuria, S. 1997. Perunggasan. Ayam dan Telur. 26:21-22. 
